\title{
Effect of $17 \beta$-Estradiol on Feminization, Growth Rate and Survival Rate of Pasific White Shrimp (Litopenaeus vannamei, Boone 1931) Postlarvae
}

\author{
I Nengah Gde Sugestya ${ }^{1 *}$, Maheno Sri Widodo ${ }^{2}$, Agoes Soeprijanto \\ ${ }^{1}$ Master Program of Fisheries and Marine Sciences, Faculty of Fisheries and Marine Sciences, University of Brawijaya, \\ Malang, Indonesia \\ ${ }^{2}$ Faculty of Fisheries and Marine Sciences, University of Brawijaya, Malang, Indonesia
}

\begin{abstract}
This study was therefore aimed to determine the effect of different concentration of estrogen hormone, 17 $\beta$-estradiol $\left(E_{2}\right)$ on feminization for the production of all female, growth rate and survival rate of Pasific white shrimp (Litopenaeus vannamei) postlarvae (PL). L. vannamei $\mathrm{PL}_{1}$ were stocked randomly at a density of 10 ind. $\mathrm{L}^{-1}$ into a $10 \mathrm{~L}$ of seawater for each experimental flask with three replicates each. $\mathrm{PL}_{1}$ was immersed in seawater containing $0.5,1.0$ and $1.5 \mathrm{mg} \cdot \mathrm{L}^{-1}$ estrogen hormone, $E_{2}$ for 4 hours. The experiment was continued for 30 days for larval rearing. At the termination of experiment, the specimens in each treatment groups were weighed and measured individually for their wet body weight (BW) and total length ( $T L$ ) for the mean weight gain, length gain and the specific growth rate (SGR) estimation. The mean sex ratio values of male to female postlarvae obtained from control till the highest $E_{2}$ hormone concentration of $0,0.5,1.0$ and $1.5 \mathrm{mg} . \mathrm{L}^{-1}$ were $1: 1,1: 2,0: 1$ and 0:1 respectively. The weight gain and length gain were $40605 \%$ and $606 \%$ for control, $46310 \%$ and $647 \%$ for $0.5 \mathrm{mg} . \mathrm{L}^{-1}$ concentration, $49310 \%$ and $663 \%$ for $1.0 \mathrm{mg} . \mathrm{L}^{-1}$ concentration and $45048 \%$ and $628 \%$ for $1.5 \mathrm{mg} . \mathrm{L}^{-1}$. The mean SGR BW and SGR TL for control till the highest $\mathrm{E}_{2}$ hormone concentration of 0, 0.5, 1.0 and $1.5 \mathrm{mg}^{\mathrm{L}} \mathrm{L}^{-1}$ were 20.00 and $6.51,20.46$ and $6.70,20.67$ and 6.77 and 20.37 and 6.62 respectively. The mean survival rate for $\mathrm{E}_{2}$ hormone concentration of $0,0.5,1.0$ and $1.5 \mathrm{mg} . \mathrm{L}^{-1}$ were $52.67 \%, 54.33 \%, 54.67 \%$ and $52.33 \%$ respectively. The study shows that while the concentration of $E_{2}$ hormone increased, the female sex ratio of $L$. vannamei PL also increased but the growth rate and survival rate decreased at concentration of $1.5 \mathrm{mg}^{-L^{-1}}$. Thus the optimum concentration of this hormone usage was $1.0 \mathrm{mg} \cdot \mathrm{L}^{-1}$ immersed for 4 hours.
\end{abstract}

Keywords: $17 \beta$-estradiol, feminization, growth rate, Litopenaeus vannamei, postlarvae, survival rate.

\section{INTRODUCTION}

In Indonesia, as in many countries, aquaculture plays an important role in increasing seafood production. Penaeid shrimp is one of the fastest growing aquaculture production sectors [1]. The Pacific white shrimp (Litopenaeus vannamei) production has rapidly increased in Asia [2]. In 2006, $88 \%$ of penaeid shrimp came from Asia, with the top five producers such as China, Thailand, Vietnam, Indonesia and India are accounting for $81 \%$ of world production [3].

Thus, an efficient biotechnology for producing all female penaeid shrimp populations is required especially in Indonesia, in which shrimp farming economically constitute an important source of income [4]. Due to the economic importance of penaeid shrimp worldwide, especially in aquaculture base production, great efforts had been developed for suitable and useful techniques. It is in order to increase the total of harvesting production goal [5]. Thus, the

\footnotetext{
* Correspondence address:

I Nengah Gde Sugestya

Email : gdesugestya@gmail.com

Address : Faculty of Fisheries and Marine Sciences, University of Brawijaya, Veteran Malang, Malang 65145.
}

requirement of market demand for shrimps in more uniform sizes, the monosex culture of female penaeid shrimps could be a strategy to produce larger shrimp is become necessary [6].

Commonly, females penaeid shrimp are growing faster and achieve a larger ultimate size than males as they are observed in wild populations $[7,8,9]$. Possibly, the larger size of females penaeid shrimp also exibhit sexdependent dimorphic growth pattern that influence females growing faster than the males [10], because females have higher food efficiency utilization and apparent digestibility of energy [7, 11]. Therefore, there is a technique that potential for monosex females culture of penaeid shrimps for decreasing growth period, increasing pond yield, and also provide significantly higher growth rate [12].

The productions of monosex population can be applied through sex reversal achieved by administering androgens or estrogens hormone. While $17 \beta$-estradiol has been shown to be an effective feminization hormone in some fish [13], the administration of the steroid in crustaceans focused on reproduction has been attemped but the results are varied and sometime inconsistent $[14,15]$. 
Some study to reverse sex in penaeid shrimps from male to female had reported successful by administering steroid hormone $17 \beta$-estradiol through prepared feed in Penaeus monodon [16] and banana shrimp (Fenneropenaeus merguiensis) [17] during postlarvae stages. But none administration of steroid hormone $17 \beta$ estradiol through immersion were reported. Thus, this study aimed to determine the effect of different concentration of immersions estrogen hormone, $17 \beta$-estradiol on feminization, survival rate and growth rate of $L$. vannamei postlarvae.

\section{MATERIALS AND METHODS}

\section{Sea Water Supply and Water Treatment}

This experiment was conducted at National Broodstock Center for Shrimp and Mollusc Karangasem, Bali, Indonesia, where the Pacific white shrimp (L. vannamei) postlarvae also obtained. The sea water source was from coastal water of Lombok Strait and pumped to the sedimentation tank and left overnight. The water was desinfected with $30 \mathrm{ppm}$ calcium hypochlorite for 16 hours without aeration, then full aeration was blown throughout the tank for 8 hours. Before use, the sea water was checked with o-Tolidine to make sure there was no chlorine left. When the o-Tolidine test result showed yellowish water, the sea water then dechlorinated with sodium thiosulfate. After that, 5 ppm EDTA added as chelating agents of heavy metals in the water. The cotton filterbag $(50 \mu \mathrm{m})$ was used to filter detritus, small organisms and turbid water while sea water being used.

\section{Experimental Design}

The culture design consisted of 12 flasks containing each $10 \mathrm{~L}$ sea water. All the flasks were put in the $8000 \mathrm{~L}$ tank containing freshwater which act as the water bath and covered with black hollow plastic to maintain stable temperature of $28-32^{\circ} \mathrm{C}$ throughout the experimental period. Aeration was distributed from a controled air blower to each flask through transparent long rubber hose which provide with an air stone. Litopenaeus vannamei postlarvae day $1\left(\mathrm{PL}_{1}\right)$ were stocked randomly at a density 10 ind. $\mathrm{L}^{-1}$, so the number of postlarvae stocked in each experimental flask is 100 individuals. The experiment consisted of immersed postlarva containing three consentrations of $E_{2}$ at $0.5,1.0$ and $1.5 \mathrm{mg} . \mathrm{L}^{-1}$ with three replicates for each treatment. Twenty five $\mathrm{PL}$ samples were weighted and measured randomly to obtain the initial body weight (BW) and total length (TL) and recorded.

\section{Hormone Immersions}

The hormone solution prepared by following method described by $[18,19]$. Stock solution of hormone prepared by weighting the amount of 0.5, 1.0 and $1.5 \mathrm{mg} . \mathrm{L}^{-1} \mathrm{E}_{2}$ hormone (Argent Laboratories Inc. Philippines) and dissolved in 1 $\mathrm{mL}$ 95\% ethanol (Merck) each. The hormon solution then poured in $1 \mathrm{~L}$ sea water each and aerated for 30 minutes to evaporate ethanol odor. Amount of $\mathrm{PL}_{1}$ L. vannamei were immersed for 4 hours in hormone solution. After completion of hormone immersion, the flasks were emptied, washed and filled with $10 \mathrm{~L}$ filtered sea water. The experiment were maintained until the end of study in this flasks.

\section{Larval Rearing}

The daily amount of feed, which include quantity and number of feeding times, were adjusted for growth and survival compensation depend on the age of shrimps. The fed were given four times a day at $07.00 \mathrm{am}, 12.00 \mathrm{am}$, $05.00 \mathrm{pm}$ and $10.00 \mathrm{pm}$ at the rate of $10 \%$ wet body weight.day ${ }^{-1}$ [20]. The experiment was continued for 30 days. Water exchange were done by siphoned out $40-50 \%$ water and also to removed uneaten food and faeces then replaced with new clean treated and filtered water.

During the study, the parameters of sea water were maintained at 28-32 ppt of salinity, more than $4 \mathrm{mg} . \mathrm{L}^{-1}$ for $\mathrm{DO}$, temperature $28-30^{\circ} \mathrm{C}$ and 7.5-8.5 for $\mathrm{pH}$. After 30 days, the shrimp postlarvae in each flasks were harvested by firstly siphoned out until the depth of water level about 2/3 left and finally shrimps collected using smooth scoop net. Postlarvae harvested from each flask was counted to determine their survival rate, and their weight and length also measured for the growth rate analysis. The shrimp postlarvae were preserved in $10 \%$ formaldehyde and put in the bottle sample according to their each concentration of treatment until their sexes observed.

\section{Sex Determination and Sex Ratio}

These external sex differentiation of each shrimp between male and female $L$. vannamei in this present study determined by examining the morphological sex structures following the protocol of previous study [10]. The females PL had a pair of oblique sharp ridges on the anterior part of sternite XIV (between the fourth and fifth pereiopods) that characterizes the female thelycum of this species. While the males PL had a masculine appendix at the second pair of pleopods and tubular appendage developed the 
gonophores complex at the medially of fifth pereiopods.

\section{Size Increasements and Spesific Growth Rate}

At the termination of the experiment (after 30 days), the biological measurement of wet body weight (BW) and total length (TL) of random $25 \mathrm{PL}$ L. vannamei from each treatment group were weighted and measured individually to estimate the mean final body weight and total length, and the spesific growth rate (SGR). A digital weighing machine (Kern brand) with an accuracy of $0.0001 \mathrm{~g}$ and a vernier calliper (Tricke Brand, Shanghai China) with an accuracy of 0.1 $\mathrm{mm}$ were use to measure the BW and TL of each $\mathrm{PL}$ shrimp, respectively. The SGR of $\mathrm{PL}$ was calculated using formula by [21].

$\mathrm{SGR}=\frac{100\left(\text { in mean final } \frac{\mathrm{BW}}{\mathrm{TL}}-\text { In mean initial } \frac{\mathrm{BW}}{\mathrm{TL}}\right)}{\text { Culture Period (days) }}$

Description:

SGR = Spesific Growth Rate

BW = Body Weight

$\mathrm{TL} \quad=$ Total Length

\section{Survival rate}

The survival $L$. vannamei $\mathrm{PL}$ were also counted at the termination of the study. Survival rate $(\%)$ is equal to number of $\mathrm{PL}$ harvested divided by number of PL stocked multiply by $100 \%$ [22].

\section{Statistical analysis}

To determine the differences among treatments, One way Analysis of variance (ANOVA) was used. Post host test and Tukey's test were used to determine the significantly different among treatment. The significance level of the results was set at $(P<0.05)$. All statistics were performed using SPSS (version 16).

\section{RESULT AND DISCUSSION Sex Ratio}

The sex ratio of experimentals groups hormone-treated L. vannamei gained from the mean of 25 individuals PL for the three replicates of each treatment. The comparison of mean sex ratio values of male : female gained from control to the highest $E_{2}$ hormone concentration of 0 , $0.5,1.0$ and $1.5 \mathrm{mg} . \mathrm{L}^{-1}$ that is $1: 1,1: 2,1: 9$ and $0: 1$, respectively. In this study, as the concentration of $E_{2}$ hormone increased from control treatment $\left(0 \mathrm{mg} . \mathrm{L}^{-1}\right)$ until the highest treatment concentration $\left(1.5 \mathrm{mg} \cdot \mathrm{L}^{-1}\right)$, the mean sex ratio values of male to female were also increased. The results obtained were significantly different $(P<0.05)$ among the treatments. The sex ratio of experimental groups hormone-treated $L$. vannamei were shown in Figure 1.

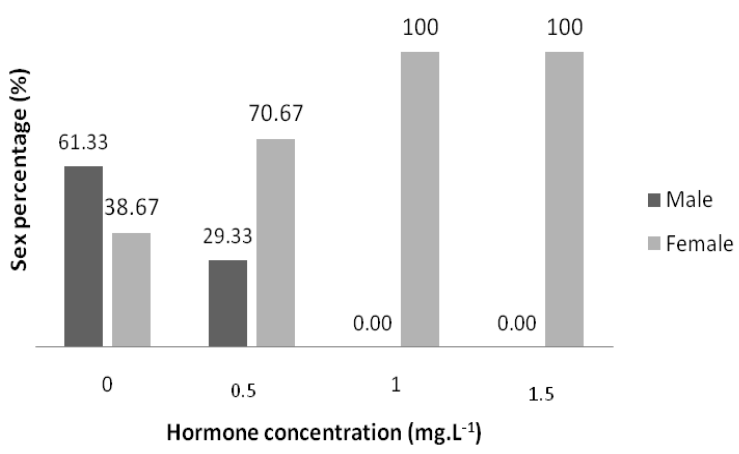

Figure 1. Sex ratio percentage of $L$. vannamei larvae between all hormone concentration (mg. $\mathrm{L}^{-1}$ ) treatments

This study, showed the administration of $E_{2}$ hormone can increase the sex reversal of the male $L$. vannamei PL into $100 \%$ females. A similar result was also obtained by previous study in blue gill sunfish, Lepomis macrochirus [23]. Thus, it can be stated that $E_{2}$ hormonal administration can produce sex reversal not only for fish species but also for Penaeid shrimps. Other studies shown consider successful feminization of tiger shrimp (Penaeus monodon) [16] and banana shrimp (Feneropenaeus merguiensis) [17] as their mean sex ratio values of male reverse to female increased as the concentration of $E_{2}$ hormone increased from control treatment to the highest treatment concentration when administration of $E_{2}$ hormone through feed was done during the early stages of their lives.

\section{Growth Rate}

The mean SGR BW for control treatment of $L$. vannamei PL after 30 days of culture was 20.00, while for $E_{2}$ hormone concentration treatments of $0.5,1.0$ and $1.5 \mathrm{mg} \mathrm{L}^{-1}$ were 20.46, 20.67 and 20.37 respectively (Fig. 2). All hormone treatment shrimp shows higher SGR BW than control with the highest SGR BW was $1.0 \mathrm{mg} . \mathrm{L}^{-1}$ hormone treatment. The same situation was obtained from SGR TL result (Fig. 3) which showed all hormone treatment shrimp have higher SGR TL than control. The results for control, 0.5, 1.0 and $1.5 \mathrm{mg} . \mathrm{L}^{-1}$ treatment were $6.51,6.70,6.77$ and 6.62 respectively. Immersions through $1.0 \mathrm{mg} \cdot \mathrm{L}^{-2} \mathrm{E}_{2}$ concentration showed the highest SGR TL from all treatments. This study showed the same results obtained from the study on bluegill sunfish, L. macrochirus that shown consider successful in administration 
of E2 hormone not only on sex reversal but as a growth promoter [23].

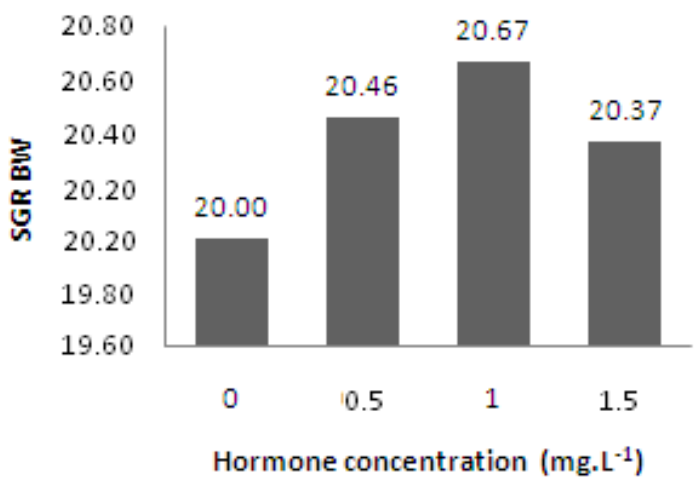

Figure 2. Mean SGR BW of L. vannamei larvae between all hormone concentration $\left(\mathrm{mg} \cdot \mathrm{L}^{-1}\right)$ treatments

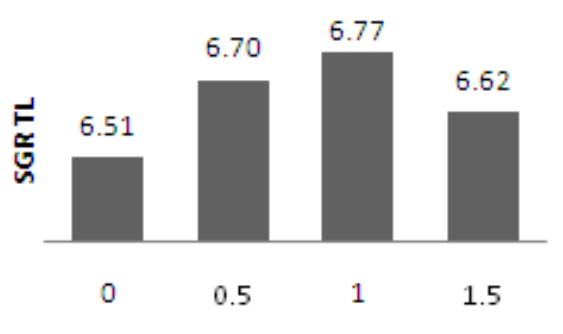

Hormone concentration (mg. $\mathrm{L}^{-1}$ )

Figure 3. Mean SGR TL of $L$. vannamei larvae between all hormone concentration $\left(\mathrm{mg} . \mathrm{L}^{-1}\right)$ treatments

The weight gain and length gain for control and all treatment were shown in Table 1 and Table 2. Control shows the lowest value of both weight gain and length gain. Hormone concentration of $1.0 \mathrm{mg} . \mathrm{L}^{-1}$ showed the highest weight gain and length gain followed by 0.5 and $1.5 \mathrm{mg} . \mathrm{L}^{-1}$ hormone concentration respectively. Highly significant difference $(P>0.05)$ was detected among the treatments.

Results of weight gain and length gain were expected to show that the hormone treatment of L. vannamei larvae gain weight and length higher and faster than normal or control larvae because $E_{2}$ also have been proved to accelerate the growth of coho salmon [24], Penaeus monodon [16] and Fenneropenaeus merguiensis [17].

The increased $E_{2}$ doses ( 0.5 and $1.0 \mathrm{mg} \cdot \mathrm{L}^{-1}$ ) had also increased the growth and size of $L$. vannamei $\mathrm{PL}$ due to the increasing somatic growth rate for each individual of the monosex population. In monosex population, the shrimp body will concentrate the energy from feed more on somatic growth than in the gonad development $[22,25]$.

Meanwhile, mean SGR BW and SGR TL and also weight gain and length gain at $1.5 \mathrm{mg} \cdot \mathrm{L}^{-1} \mathrm{E}_{2}$ concentration decreased. One of the possible reason for their decreasing because of the high concentration of $E_{2}$, as also reported that $17 \beta$ estradiol at $62.5 \mu \mathrm{g} . \mathrm{L}^{-1}$ and higher levels may cause growth suppression and low survival rate for mysid shrimp Americamysis bahia [26].

Table 1. Weight Gain (\%) L. vannamei Larvae Between All Hormone Concentration (mg. $\mathrm{L}^{-1}$ ) Treatments

\begin{tabular}{cccc}
\hline $\begin{array}{c}\text { Hormone } \\
\text { doses } \\
\text { (mg.t }\end{array}$ & $\begin{array}{c}\text { Initial mean } \\
\text { weight }(\mathrm{g})\end{array}$ & $\begin{array}{c}\text { Final mean } \\
\text { weight }(\mathbf{g})\end{array}$ & $\begin{array}{c}\text { Weight } \\
\text { gain } \\
(\%)\end{array}$ \\
\hline 0.0 & $0.0007 \pm 0.0003$ & $0.2849 \pm 0.047$ & 40605 \\
0.5 & $0.0007 \pm 0.0003$ & $0.3249 \pm 0.018$ & 46310 \\
1.0 & $0.0007 \pm 0.0003$ & $0.3459 \pm 0.024$ & 49310 \\
1.5 & $0.0007 \pm 0.0003$ & $0.3160 \pm 0.011$ & 45048 \\
\hline
\end{tabular}

Table 2. Length Gain (\%) L. vannamei Larvae Between All Hormone Concentration (mg. $\mathrm{L}^{-1}$ ) Treatments

\begin{tabular}{cccc}
\hline $\begin{array}{c}\text { Hormone } \\
\text { doses }\left(\mathbf{m g . ~}^{-1}\right)\end{array}$ & $\begin{array}{c}\text { Initial mean } \\
\text { length }(\mathbf{m m})\end{array}$ & $\begin{array}{c}\text { Final mean } \\
\text { length }(\mathbf{m m})\end{array}$ & $\begin{array}{c}\text { Length } \\
\text { gain (\%) }\end{array}$ \\
\hline 0.0 & $5.05 \pm 0.74$ & $35.30 \pm 2.10$ & 606 \\
0.5 & $5.05 \pm 0.74$ & $37.30 \pm 0.83$ & 647 \\
1.0 & $5.05 \pm 0.74$ & $38.20 \pm 1.36$ & 663 \\
1.5 & $5.05 \pm 0.74$ & $36.40 \pm 0.65$ & 628 \\
\hline
\end{tabular}

\section{Survival Rate}

Survival rate of each treatment group was calculated based on mean of three replicates. The highest mean percentage of survival rate was recorded for $1.0 \mathrm{mg} . \mathrm{L}^{-1} \mathrm{E}_{2}$ hormone treatment at $54.67 \pm 1.53 \%$ while the lowest mean percentages was recorded for $1.5 \mathrm{mg}^{-L^{-1}} \mathrm{E}_{2}$ at $52.33 \pm 3.79 \%$. The survival rate was increase started from $0.5 \mathrm{mg} . \mathrm{L}^{-1} \mathrm{E}_{2}$ at $54.33 \pm 1.15 \%$ to 1.0 mg. $L^{-1} E_{2}$ at $54.67 \pm 1.53 \%$ and slightly decreased at $1.5 \mathrm{mg} \cdot \mathrm{L}^{-1} \mathrm{E}_{2}$ at $52.33 \pm 3.79 \%$ (Fig. 4). Highly significant difference $(P>0.05)$ was detected among the treatments.

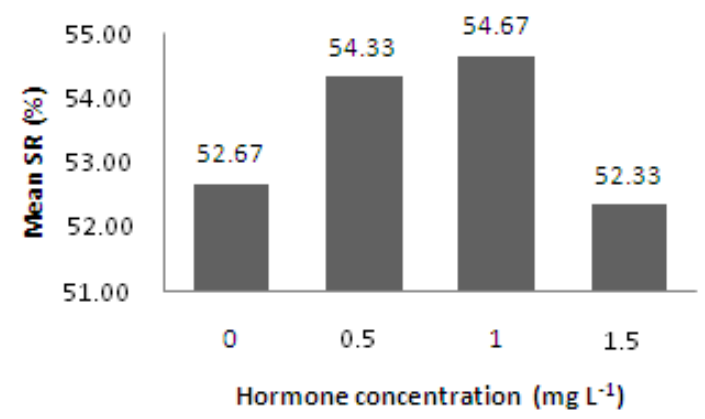

Figure 4. Mean Survival Rate of L. vannamei PL Immersed with Different $E_{2}$ Hormone Concentration.

The survival rate of $1.5 \mathrm{mg} \cdot \mathrm{L}^{-1} \mathrm{E}_{2}$ hormone treated L. vannamei postlarvae were slightly lower comparing with control. It was not surprising because $17 \beta$-estradiol treatments result in higher mortality of most aquaculture 
spesies [27-31]. It was suggested that the $L$. vannamei $\mathrm{PL}$ are in the stress with the increasing of $E_{2}$ concentrations in their body that will over react their body metabolism thus produced lower survival rate. Based on those result, we conclude that the optimum concentration for the growth and survival rates was $1.0 \mathrm{mg} \cdot \mathrm{L}^{-1}$ of $\mathrm{E}_{2}$.

\section{CONCLUSION}

The present study demonstrates that the usage of estrogen hormone, 17 $\beta$-estradiol through immersion can be an effective method for the production of $100 \%$ female $L$. vannamei $\mathrm{PL}$ at lowest concentration of $1.0 \mathrm{mg} \cdot \mathrm{L}^{-1} \mathrm{E}_{2}$. The results also showed that $E_{2}$ hormone can be acted as a growth promoter in penaeid shrimp ( $L$. vannamei) PL either the growth rate and survival rate decrease when the hormone concentration increasing. It also concludes that the optimum concentration of $17 \beta$-estradiol was $1.0 \mathrm{mg} . \mathrm{L}^{-1}$ for the best feminization, growth and survival rate of L. vannamei.

\section{ACKNOWLEDGEMENT}

This study was fully funded by a research grant from BPSDMKP, Ministry of Fisheries and Marine Affair. The authors wish to thank all the staff from National Broodstock Center for Shrimp and Mollusc Karangasem, Bali and Faculty of Fisheries and Marine Science for all the help which made this study possible.

\section{REFERENCES}

[1] Jiang, S.G., J.H. Huang, F.L. Zhou, X. Chen, Q.B. Yang, W.G. Wen, Z.M. Ma. 2009. Observations of reproductive development and maturation of male Penaeus monodon reared in tidal and earthen ponds. Aquaculture. 292. 121-128.

[2] FAO. 2010. The state of world fisheries and aquaculture. Available at: www.fao.org/ docrep/013/i1820e/i1820e01.pdf.

[3] FAO. 2008. The state of world fisheries and aquaculture. Available at: ftp://ftp.fao.org /docrep/fao/009/a0699e/a0699e.pdf.

[4] Sagi, A., E.D. Aflalo. 2005. The androgenic gland and monosex culture in Taiwan: A biotechnological perspective. Aquacult. Res. 36. 231-237.

[5] Franco, A.R., J.G. Ferreira, A.M. Nobre. 2006. Development of a growth model for penaeid shrimp. Aquaculture. 259. 268-277.

[6] Gomelsky, B. 2003. Chromosome set manipulation and sex control in common carp: A review. Aquatechnol. Living Resour. 16. $408-415$.
[7] Gopal, C., G. Gopikrishna, G. Krishna, S.S. Jahageerdar, M. Rye, B.J. Hayes, S. Paulpandi, R.P. Kiran, S.M. Pillai, P. Ravichandran, A.G. Ponniah, D. Kumar. 2010. Weight and time of onset of femalesuperior sexual dimorphism in pond reared Penaeus monodon. Aquaculture. 300. 237239.

[8] FAO. 2006. Cultured aquatic species information programme Penaeus vannamei (Boone, 1931). Fishery Statistics. Italy.

[9] Perez-Rostro, C.L., A.M. Ibarra. 2003. Heritabilities and genetic correlations of size traits at harvest in sexually dimorphic Pacific White Shrimp (Litopenaeus vannamei) grown in two environments. Aquacult. Res. 34. 1079-1085.

[10] Campos-Ramos, R., R. Garza-Torres, D.A. Guerrero-Tortolero, A.M. Maeda-Martinez, H. Obregon-Barboza, 2006. Environmental sex determination, external sex differentiation and structure of the androgenic gland in the Pacific White Shrimp, Litopenaeus vannamei (Boone). Aquacult. Res. 37. 1583-1593.

[11] Moss, D.R., S.M. Moss. 2006. Effects of gender and size on feed acquisition in the Pacific White Shrimp Liptopenaeus vannamei. J. World Aquac.Soc. 37. 161-167.

[12] Hansford, S.W., D.R. Hewitt. 1994. Growth and nutrient digestibility by male and female Penaeus monodon: evidence of sexual dimorphism. Aquaculture. 125. 147154.

[13] Padian, T.J., S.G. Sheela. 1995. Hormonal induction of sex reversal in fish. Aquaculture. 138. 1-22.

[14] Okumura, T. 2004. Perspective on hormonal manipulation of shrimps reproduction. Jpn. Agric. Res. Q. 38. 49-54.

[15] Wilder, M.N., T. Subramoniam, K. Aida. 2002. Yolk protein of Crustacea. In: Raikhel, A.S, T.W. Sappington (Eds). Reproductive Biology of Invertebrates Vol. XIIA Progress in Vitellogenesis. Science Publishers, Enfield, NH, USA. 131-174.

[16] Hafiz, M.B., M. Hidayah, A.Y. Yusdianatu, M.A. Ambak, A.B. Abol-Munafi, M. Ikhwanuddin. 2012. Effect of estrogen Hormone, 17 $\beta$-Estradiol on feminization, survival rate and growth rate of Tiger Shrimp, Penaus Monodon (Fabricius, 1798) Postlarvae. Borneo Sci. 30. 70-80.

[17] Hafiz, M.B., J. Safiah, A.B. Abol-Munafi, M. Ikhwanuddin. 2012. Effect of estrogen 
hormone, 17 $\beta$-estradiol on feminization, survival and growth rate of Banana Shrimp, Fenneropenaeus merguiensis (De Man, 1888) Postlarvae. UMT $11^{\text {th }}$ International Annual Symposium on Sustainability Science and Management. Terengganu, Malaysia. 84-90.

[18] Rosmaidar, D. Aliza, J. Ramadhanita. 2014. Pengaruh lama perendaman dalam hormon metiltestoteron alami terhadap pembentukan kelamin jantan larva Ikan Nila (Oreochromis niloticus). Jurnal Medika Veterinaria. 8(2). 853-1943.

[19] Aktas, M., M.A. Genc. 2011. The effect of $17 \beta$-Estradiol on growth, survival and feminization of Green Tiger Shrimp, $P$. semisulcatus (Decapoda: Penaeidae). J. Anim. Vet. Adv. 10(5). 562-565.

[20] Kian, A.Y.S., S. Mustafa, R.A. Rahman. 2004. Use of enriched live prey in promoting growth and maturation of Tiger Shrimp (Penaeus monodon). NAGA, Worldfish Center Q. 27 (1\&2). 55-59.

[21] Bautista-Teruel, M.N., P.S. Eusebio, T.P. Welsh. 2003. Utilization of feed Pea, Pisum Sativum, meal as a protein source in practical diets for juvenile Tiger Shrimp, Penaeus monodon. Aquaculture. 225. 121131.

[22] Ikhwanuddin, M., A.D. Talpur, O. Zulizah, A.M. Hidayah, A.A. Shamsuddin, A.B. AbolMunafi, 2012. The masculine effect of the androgen hormone, $17 \alpha$ - methyltesterone for the production of all male postlarvae of tiger shrimp, Penaeus monodon (Fabricius, 1798) postlarvae. Int. J. Current Res. 4(10). 59-64.

[23] Wang, H.P., Z. Gao, B. Beres, J. Ottobre, G. Wallat, L. Tiu, D. Rapp, P. O'Bryant, H. Yao. 2008. Effects of Estradiol-17 $\beta$ on survival, growth performance, sex reversal and gonadal structure of Bluegill Sunfish, Lepomis macrochirus. Aquaculture. 285. 216-223.

[24] Ashby, K.R. 1957. The effect of steroid hormones on the brown trout (Salmo trutta L.) during the period of gonadal differentiation. J. Embryol. Exp. Morphol. 5. 225-249.

[25] Sagi, A., E.D. Aflalo. 2005. The androgenic gland and monosex culture of Freshwater Prawn Macrobrachium rosenbergii (De Man): a biotechnological perspective. Aquac. Res. 36. 231-237.
[26] Hirano, M., H. Ishibashi, N. Watanabe, N. Matsumura, A. Watanabe. 2004. Effects of $17 \beta$-estradiol on survival, growth, sexual development and molting cycles of the marine Crustacean Mysid Shrimp, Amerycamysis bahia. Environ. Sci. 11. 259268

[27] Karayucel, I., O.K. Orhan, S. Karayucel. 2006. Effect of different levels of $17 \alpha$ methyltestosterone on growth and survival of Angelfish (Pterophyllum scalare Lieechtenstein, 1923) fry. J. Anim. Vet. Adv. 5. 244-248.

[28] Kirankumar, S., V. Anaty, T.J. Pandian. 2003. Hormonal induction of super male golden rosy barb and isolation of Y-chromosome specific markers. Gen. Comp. Endocrinol. 134. 62-71.

[29] Kim, D.S., Y.K. Nam, J.Y. Jo. 1997. Effect of $17 \beta$-estradiol immersion treatment of sex reversal of Mud Loach Misgurnus mizolepis (Gunther). Aquacult. Res. 28. 941-946.

[30] Herman, R.L., H.L. Kincaid. 1988. Pathological effects of orally administered estradiol to Rainbow Trout. Aquaculture. 72. 165172.

[31] Sower, S.A., W.W. Dickhoff, J. Mighell, T. Flagg, C. Mahnken. 1984. Effects of estradiol and diethylstilbestrol on sex reversal and mortality in Atlantic Salmon (Salmo salar). Aquaculture. 43. 75-82. 